\title{
Profitability analysis of compost barn and free stall milk-production systems: a comparison
}

\section{Análise de rentabilidade de sistemas de produção de leite em compost barn e free stall: um comparativo}

\author{
Gustavo Rafael de Oliveira Silva ${ }^{1}$; Marcos Aurélio Lopes ${ }^{2 *}$; \\ André Luís Ribeiro Lima ${ }^{3}$; Geraldo Márcio da Costa ${ }^{3}$; Flávio Alves Damasceno ${ }^{3}$; \\ Vitor Pires Barros ${ }^{4}$; Matteo Barbari ${ }^{5}$
}

\begin{abstract}
The objective of this study was to comparatively analyse the profitability of compost barn and free stall milk-production systems as a means of helping producers and technicians choose the type of facility most suitable for each farm. Data collected from four farms from January to December 2016 were analysed; the data were distributed equally among compost barn and free stall systems. The cost of milk production was estimated according to the operating cost methodology and considering the milk production cost centre, which involved both lactating and dry cows. Additionally, gross and net margins were estimated as indicators of profitability. The results showed that the average gross and net margins were not influenced by the type of facility; they were positive in both of the production systems analysed. Among the components of the net operating cost, the proportion of the "medications" item was lower in the compost barn properties, while the cost of bedding for the cows was lower in the free stall farms. Depreciation and total operating cost were similar in the two systems. Milk sales made up a higher percentage of the revenue in the free stall farms, despite the high standard deviation, while the expectations of revenues from wastes were similar in the two production systems. Given that there were no significant economic differences between the types of facility, it is concluded that ease in management, productivity, reproductive performance, animal health (hoof injuries and mastitis), environmental issues, and availability of water and bedding material should be the motivators for choosing one system over the other.
\end{abstract}

Key words: Dairy cattle. Cost centers. Production cost. Animal facility.

\section{Resumo}

Objetivou-se analisar, comparativamente, a rentabilidade de sistemas de produção de leite que utilizam compost barn e free stall, visando auxiliar produtores e técnicos a escolher o tipo de instalação mais adequada para cada fazenda. Foram analisados dados de janeiro a dezembro de 2016 de quatro fazendas, distribuídas igualmente para o compost barn e para, o free stall. O custo de produção do leite foi estimado segundo a metodologia do custo operacional, considerando o centro de custos produção de leite, que

\footnotetext{
1 Discente, Curso de Mestrado do Programa de Pós-Graduação em Ciências Veterinárias, Universidade Federal de Lavras, UFLA, Médico Veterinário do Recursos Humanos no Agronegócio - Rehagro, Lavras, MG, Brasil. E-mail: gustavo.silva@rehagro.com.br

2 Prof. Titular, UFLA, Lavras, MG, Brasil. E-mail: malopes@ufla.br

3 Profs., UFLA, Lavras, MG, Brasil. E-mail: andreluisnep@yahoo.com.br; marciocostavet@gmail.com; flavio.damasceno@ufla.br;

4 Médico Veterinário, Rehagro, Belo Horizonte, MG, Brasil. E-mail: vitor.barros@rehagro.com.br

5 Prof., Università degli Studi di Firenze, Florença, Itália. E-mail: matteo.barbari@unifi.it

* Author for correspondence
} 
envolveu as vacas em lactação e as secas. Adicionalmente, foram estimadas as margens bruta e líquida, como indicadores de rentabilidade. Observou-se que as médias das margens bruta e líquida não foram influenciadas pelo tipo de instalação, sendo positivas em todos os sistemas de produção analisados. Dentre os componentes do custo operacional efetivo, a representatividade do item medicamentos foi menor nas propriedades com compost barn, enquanto o custo com cama para vacas foi menor nas fazendas com free stall. Tanto a depreciação, quanto o custo operacional total, foram semelhantes. Em relação às receitas, a venda de leite teve maior percentual nas fazendas de free stall, apesar do alto desvio padrão, e as expectativas de receitas de dejetos foram semelhantes entre os sistemas de produção. Dessa forma, visto que não houve diferenças econômicas expressivas entre os tipos de instalações, entende-se que as facilidades de manejo, produtividade, desempenho reprodutivo, saúde dos animais (lesões de casco e mastite), questões ambientais, além de disponibilidade de água e material de cama devem ser os motivadores da escolha de uma em detrimento da outra.

Palavras-chave: Bovinocultura leiteira. Centros de custos. Custo de produção. Instalação animal.

\section{Introduction}

In Brazil, two intensive systems are used to produce milk from cattle in confinement: the free stall system and the compost barn system. The latter has only recently been introduced into the country. The free stall system, which was created in 1960 in the state of Washington in the United States (ALBRIGHT, 1964), consists of a covered shed with individual beds (usually of sand), with free access for the animals and concrete corridors for accessing the troughs and drinking fountains. Twice a day, the excrement is removed from the beds using hoes, and the corridors are scraped and/ or flushed with a large volume of water to remove the urine, faeces, and sand present on the concrete surface. The sand of the beds must be replaced as it diminishes, and the need for replacement can vary from one farm to another.

The compost barn system consists of a covered shed with an undivided bedding area in which the animals can rest and where composting takes place and a feeding lane (BARBERG et al., 2007). Barberg et al. (2007) reported that the first compost barn was built in 2001 in the state of Minnesota, United States; this system only began to be used in Brazil in 2012 (BRITO, 2016). There has been widespread acceptance of this model in Brazil due to the high degree of satisfaction of producers worldwide with its functioning. According to Barberg et al. (2007), all 12 producers using the compost barn system who participated in their research in Minnesota in the
United States indicated satisfaction with the system. Similar results were reported by Black et al. (2013), who also studied compost barns in the United States (state of Kentucky). Of the 42 producers interviewed, 41 said they were satisfied. Leso et al. (2013) corroborated these results, reporting that most of the 10 producers interviewed in Italy said they were satisfied with the compost barn system and mentioning increased animal comfort as the main benefit of this system.

Various studies have addressed the dimensions (JANNI et al., 2007; KLAAS et al., 2010), installation cost (PETZEN et al., 2009), and parameters to be measured in a compost barn (BLACK et al., 2013), and other works cite possible advantages of the system in relation to reproduction (BARBERG et al., 2007), mastitis (LESO et al., 2013), and hoof injuries (LOBECK et al., 2011). However, no study has reported a profitability analysis of compost barn systems. Additionally, it is known that production costs vary from year to year given that the cost depends on innumerable variables such as the price of inputs, wages, and the technology used at the time and is also influenced by genetics and animal nutrition. Therefore, it is critical to conduct new research on production costs that includes properties that use the free stall system, thus enabling the comparison of compost barn and free stall farms. Few studies were found that adopted the cost centre methodology (LOPES et al., 2007b; SANTOS; LOPES, 2012) used in the current study. 
Thus, due to the lack of studies that have economically compared compost barn and free stall production systems, the aim of this study was to comparatively analyse the profitability of compost barn and free stall milk production systems. Specifically, this study aimed to: a) analyse and compare the proportions of total operating cost represented by various types of expenditures in each type of facility; (b) analyse and compare the proportions of expenditures related to mastitis and reproduction; c) estimate and compare gross and net margins; d) analyse and compare the proportions of the items that make up the gross revenue; and e) assist producers and technicians in choosing the type of facility most suitable for each farm.

\section{Material and Methods}

Data from four farms were collected from January to December 2016 and analysed. Two of these farms (farms 1 and 2) use the compost barn system, and two (farms 3 and 4) use the free stall system. All of the farms have the following characteristics: use of maize silage (Zea mays) as the main forage, herds predominantly of the $15 / 16 \mathrm{HG}$ genetic group, three daily milkings, and use of semen from Holstein bulls.

Farm 1 is located in Itaúna-MG, and milk production is its sole activity. It has used the compost barn system since September 2015. The bedding is composed of sawdust and is provided in an amount of $9 \mathrm{~m}^{2} / \mathrm{cow}$. The daily milk production in 2016 was $8,459 \mathrm{~kg}$, with an average of $27.3 \mathrm{~kg} / \mathrm{cow} /$ day and an average of 310 lactating cows. Farm 2, located in Tiros-MG, also began using the compost barn system in 2015; in addition to dairy farming, it has been active in coffee production. As a way of integrating the activities, the coffee husks from the plantations are used as bedding for the cows and complemented with sawdust, thus providing 10 $\mathrm{m}^{2} /$ cow. In 2016, milking 180 cows, the property produced $5,970 \mathrm{~kg}$ of milk per day on average with an average yield of $33.1 \mathrm{~kg} / \mathrm{cow} /$ day.
Farm 3, which is located in Ilicínea-MG, has been involved in the production of beans, coffee, soybeans, and milk. The free stall system has been used on the property since 2006. The bedding consists of sand, and the stocking rate (number of animals/bed) was $100 \%$ during the observation period. Unlike the other three properties, the facility did not have fans and sprinklers, and the animals were only cooled in the waiting room. The farm had a daily milk production of $9,693 \mathrm{~kg}$, with an average of $21.1 \mathrm{~kg} / \mathrm{cow} /$ day in 2016 with 459 cows milked per day on average. Farm 4 is in Formiga-MG, and it produces maize, soybeans, and milk. The cows at this farm have been housed in a free stall facility since 2013. Sand is also used as bedding, and the stocking rate was $100 \%$ during the study period. In 2016 , daily production was $8,317 \mathrm{~kg}$ of milk, with an average of $23.1 \mathrm{~kg} / \mathrm{cow} /$ day and an average of 360 lactating cows.

The farms were chosen using non-probabilistic sampling by judgement, taking into account the following criteria: availability and quality of the zootechnical and economic data; consent and interest of the farmers in conducting the study; and ease of access for the researchers to the sources of the evidence (LOPES et al., 2015).

In the present study, the total operating cost (TOC) of milk production was estimated using the methodology proposed by Matsunaga et al. (1976). Additionally, the gross margin and the net margin were calculated as profitability indicators, and analysis and comparison of the proportions of the items that make up the gross revenue, as well as the components of the TOC, was performed in accordance with Lopes et al. (2004a). All these indicators were presented considering the milk produced (milk sold, discarded, and consumed by employees) and not simply the milk sold to the dairy factory; that is, the values in reals per litre were calculated by dividing the revenues, costs, and gross and net margins by the amount of milk produced. It is important to emphasize that the value of the discarded milk was computed as $\mathrm{R} \$ 0.00$; therefore, 
it was not considered to be revenue and was used only for inclusion in the value of the milk produced, by which the values were divided.

The costs and revenues related to the milk production cost centre for the maintenance of both lactating and dry cows were taken into account and allocated into specific groups for the cost and revenue centre in question. Within each broader group, specific managerial accounts that enabled detailed comparison of the costs of the compost barn system with those of the free stall system in $\mathrm{R} \$ /$ litre of milk produced and in \% of effective operating cost (EOC) and TOC were established. The TOC included the feeding costs, reproductive inputs, sanitation, reproductive hormones, bovine somatotropin (bST), milking, labour, machine rent, energy, miscellaneous expenses, and depreciation, whereas revenues included the sales of milk, animals, bedding from the compost barn system, and manure from the free stall system, in accordance with Lopes et al. (2004a).

A complete inventory of the specific installations of the compost barn and free stall systems was conducted, and the value and the useful life of each asset in relation to the acquisition time were determined. If a milk producer could not provide information on values and acquisition dates, criteria proposed by Lopes et al. (2004b) were used to estimate updated values and remaining useful life results.

Each improvement was measured to obtain the area in $\mathrm{m}^{2}$; a conservation status was assigned, and a summary of the description memorandum was recorded with the aim of assisting in estimating the current value. The value per $\mathrm{m}^{2}$ of construction was estimated as a function of the area, the conservation status, and the finished standard. The current value was the product of the $\mathrm{m}^{2}$ value and the area of the improvement, as per Lopes et al. (2004a). The land value, in turn, was estimated by the owner of each farm, who was the person who best knew the price of the land in the region where the property was located. The operational break-even point was calculated according to Lopes et al. (2015) using the following formula: depreciation divided by the milk revenue subtracted from the EOC.

In relation to the expectation of revenue from wastes, an estimate was made of the amount of waste generated in each of the systems; then, by comparison with the price of one kilogram of nitrogen $(\mathrm{N})$, phosphorus $(\mathrm{P})$, and potassium $(\mathrm{K})$ from chemical fertilizers, the value of the waste produced in the facilities was quantified. In the free stall properties, it was not possible to measure the volume of manure produced. Therefore, an estimate of the amount produced per cow was made using the equations proposed by ASAE (2005). Based on the chemical analysis of manure presented by Kiehl (1985), the amounts of N, P, and K produced were estimated. For $\mathrm{N}$, the use of only $50 \%$ of this nutrient was considered due to losses to the atmosphere (in the form of ammonia). Thus, it was possible to estimate the price of this by-product and to consider it as an expectation of revenue from the free stall system.

For the farms using the compost barn system, the volume of bedding present in the shed after one year of use was estimated. Based on the density $\left(\mathrm{g} / \mathrm{cm}^{3}\right)$ of the bedding, the number of $\mathrm{kg}$ of this material contained in the facility was determined, and from the chemical analysis (performed in the Labras laboratory for agricultural and environmental analyses), it was possible to know the percentages of $\mathrm{N}, \mathrm{P}$, and $\mathrm{K}$. The use of $70 \%$ of the $\mathrm{N}$ produced was assumed since, according to Kiehl (1985), $\mathrm{N}$ loss can vary depending on the humidity and temperature of the compost. Thus, the price of the compost barn bedding was determined and was computed as an expectation of revenue from this production system.

In the present work, the revenues from wastes of the compost barn and free stall systems were presented separately as revenue expectations given that they did not actually generate revenue for the producers but had the potential to do so. 
The data recording and the profitability analysis were conducted using Ideagri software and Microsoft Office Excel spreadsheets. The task of entering data into the system was performed daily by farm staff; on a monthly basis, the data were audited by the veterinarian responsible from Rehagro, which provides financial consulting to the farms. Using the MS Excel application, the data were compared via descriptive analyses and grouped into tables with the aim of achieving better comparison, discussion, and presentation of the results (LOPES et al., 2004a).

\section{Results and Discussion}

Among the available resources, land equity was the most representative item in both of the production systems evaluated (Table 1), corroborating the observation of Santos and Lopes (2012). These researchers reported that the value of land on farms using a free stall confinement system accounted for $58.55 \%$ of the money invested in the property without taking into account the value of the animals. However, in the present study, the value of the land equity was more significant in the compost barn farms (Table 1) because they are located in regions in which land is more valuable.

Table 1. Comparison of the average amounts of resources available in compost barn and free stall production systems located in the state of Minas Gerais for the period January to December 2016.

\begin{tabular}{lcccc}
\hline \multirow{2}{*}{ Specification } & \multicolumn{2}{c}{ Compost barn* } & \multicolumn{2}{c}{ Free stall* $^{*}$} \\
\cline { 2 - 5 } & Average & $\%$ & Average & $\%$ \\
\hline Land equity value (R\$) & $4.920 .000,00$ & 62,64 & $2.545 .000,00$ & 53,26 \\
Value of assets without accounting for animals or land (R\$) & $2.933 .850,88$ & 37,36 & $2.233 .670,54$ & 46,74 \\
Value of improvements (R\$) & $1.622 .764,00$ & 55,31 & $1.313 .236,25$ & 58,79 \\
Value of equipment (R\$) & $411.468,13$ & 14,02 & $463.410,04$ & 20,75 \\
Value of implements (R\$) & $321.368,75$ & 10,95 & $265.709,36$ & 11,90 \\
Value of machinery (R\$) & $400.625,00$ & 13,66 & $128.179,89$ & 5,74 \\
Value of vehicles (R\$) & $177.625,00$ & 6,05 & $63.135,00$ & 2,83 \\
Total fixed assets (R\$) & $7.853 .850,88$ & 100,00 & $4.778 .670,54$ & 100,00 \\
Area (ha) & 100 & - & 111 & - \\
Average number of lactating cows (head) & 245 & - & 410 & - \\
Average daily milk production (kg/day) & 7.215 & - & 9.005 & - \\
Total fixed assets per ha (R\$) & $79.769,45$ & - & $44.236,29$ & - \\
Total fixed assets per lactating cow (R\$) & $35.761,64$ & - & $11.809,54$ & - \\
Total fixed assets per kg of milk produced per day (R\$) & $1.148,26$ & - & 533,19 & - \\
\hline
\end{tabular}

Source: Data from the study (2018)

* information from two properties; average exchange rate in 2016: US\$1 $=\mathrm{R} \$ 3.48$.

When analysing the capital invested in the compost barn and free stall farms without considering animals or land, it could be seen that a higher percentage of capital was invested in the "improvements" item (Table 1), once again confirming the results of Santos and Lopes (2012). However, in the free stall confinement systems, those researchers reported an even greater proportion of $75 \%$. Without considering the animals, the immobilized total investment value per hectare, per lactating cow, and per $\mathrm{kg}$ of milk produced per day was higher in the compost barn properties than in the free stall farms due to the high value invested in land in the former properties (Table 1). 
Table 2 shows the average values for the components of production cost in compost barn and free stall production systems in total value and in reals per litre of milk, together with their respective proportions in relation to the EOC and the TOC. The feeding cost, which is the main cost of dairy farms (CORRÊA et al., 2017; FERRAZZA et al., 2017; LOPES et al., 2015; SANTOS; LOPES, 2012; TEIXEIRA JÚNIOR et al., 2016; VILLELA et al., 2017), was similar in the two production systems (Table 2). This occurred because in both facilities the same type of feed can be used, and feed is supplied to the animals in the same way as a total diet using a forage wagon. Moreover, in both systems, good thermal comfort conditions could be offered through the use of fans and sprinklers; according to Hill and Wall (2017), this is a factor that affects dry matter consumption, milk production, and feed conversion.

Additionally, the animals at the four studied farms are from the $15 / 16 \mathrm{HG}$ genetic group; that is, they are derived mainly from the Holstein breed, which, according to Hooven et al. (1968), has high potential for milk production and high feed efficiency. However, in the farms where the animals are housed in a free stall system, the wastes from the shed were used as fertilizer for maize crops; therefore, a reduction in the cost of forage was expected due to the reduction in the use of chemical fertilizers. On the other hand, the lower production of milk per animal in these properties may have prevented the reduction in the cost of silage production from being reflected in the proportion of the forage costs of the free stall farms. The proportion of feed in the farms studied was similar to that found by Lopes et al. (2004b) but greater than that observed by Santos and Lopes (2012); the values obtained in free stall confinement systems by these authors were $60.38 \%$ and $53.19 \%$, respectively.
The "labour" item, the second most significant cost of milk production (SANTOS; LOPES, 2012), was more representative in the farms that adopted the compost barn system (Table 2). However, apart from the fact that the difference between the values is small, higher expenditure on labour does not seem to be a characteristic of the compost barn system given that the standard deviation of these properties was high $( \pm 2.83 \%)$ due to the high labour cost at farm 1 . The "third-party services" item of this farm (4.91\%) was mainly responsible for increasing the proportion of its labour force and, consequently, the average of the two farms that adopted the compost barn system. However, in farm 2, labour costs represented $13.24 \%$ of the EOC, indicating lower expenditure than in the two free stall farms, which had values of $13.33 \%$ and $14.88 \%$. Thus, the proportion of the cost of production represented by labour costs did not appear to be significantly different in the two types of systems.

According to Lopes et al. (2004b) and to Santos and Lopes (2012), the proportions of EOC represented by labour for free stall confinement systems were $16.72 \%$ and $15.81 \%$, respectively, very similar to the values found in the present study. Lopes et al. (2015) reported that the proportions of labour cost in farms with low and medium technological levels were only $3.90 \%( \pm 5.08)$ and $5.63 \%( \pm 6.43)$, respectively, due to the use of family labour on these farms. In production systems with a high technological level, these researchers reported a labour expense of $21.25 \%( \pm 2.55)$ of the EOC; this differed from the predicted value because as the use of technology increases, the automation of various processes in a property is expected. 


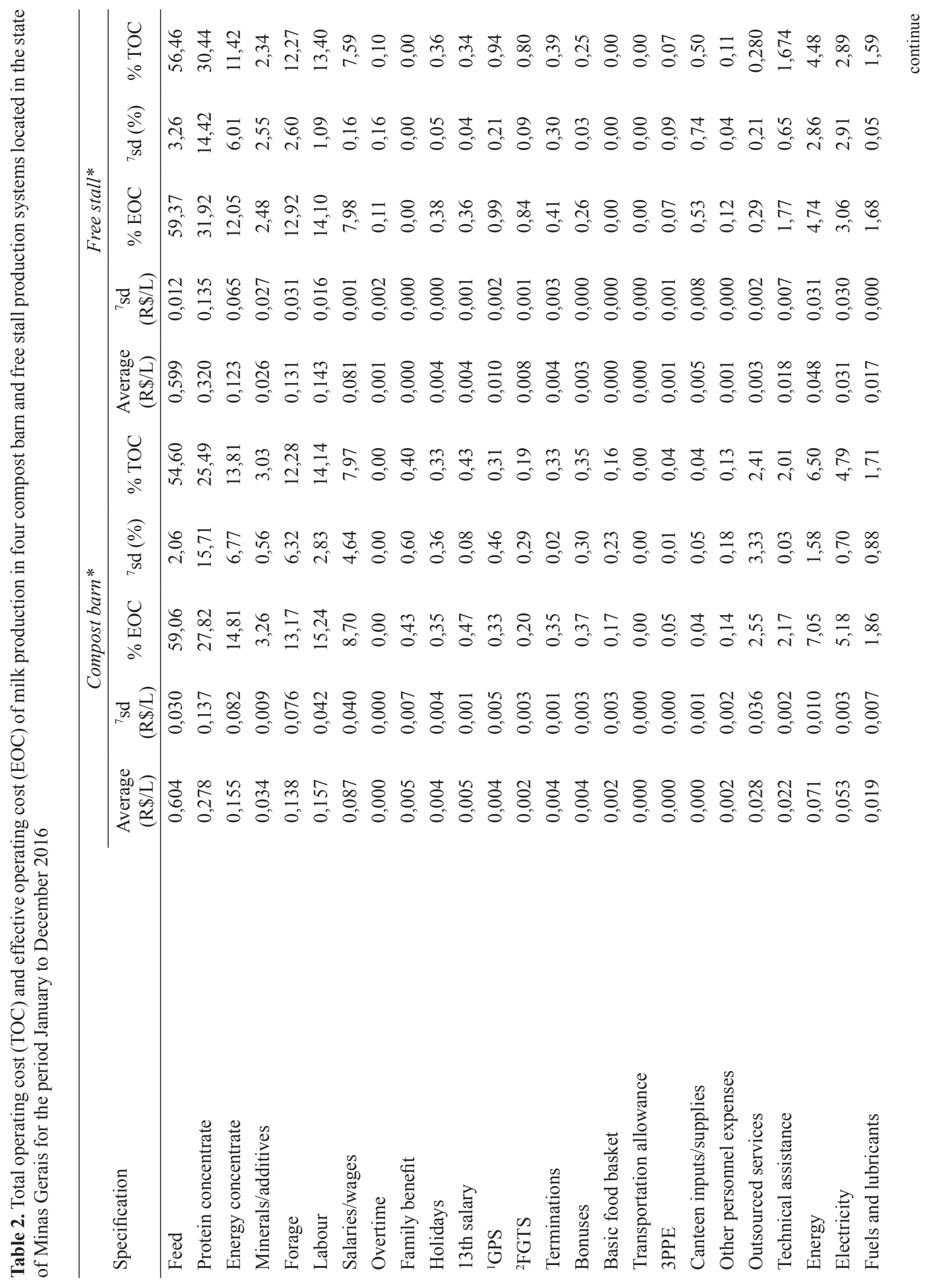




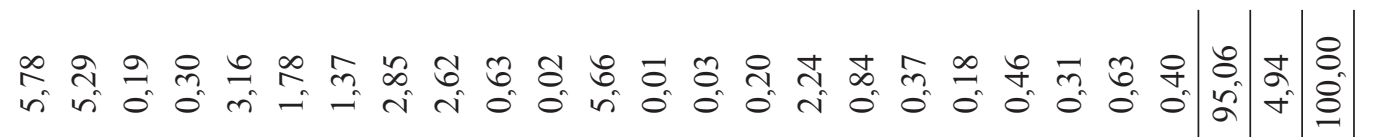

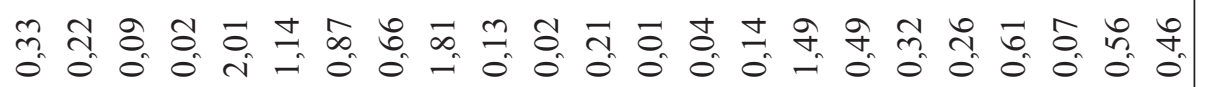

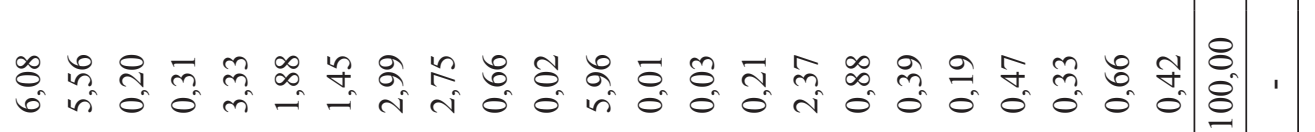

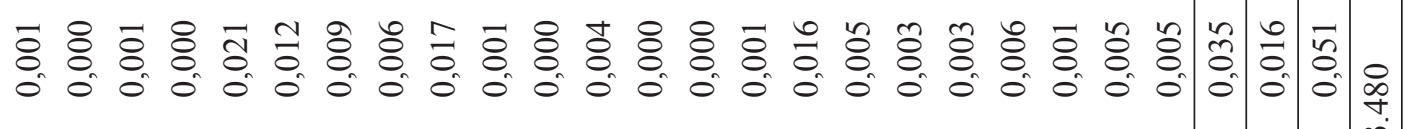

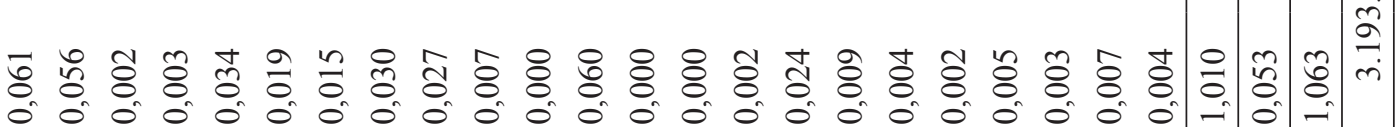

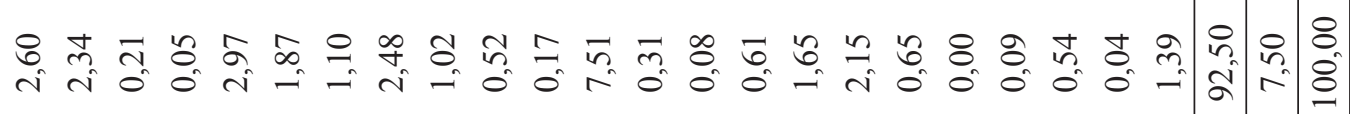

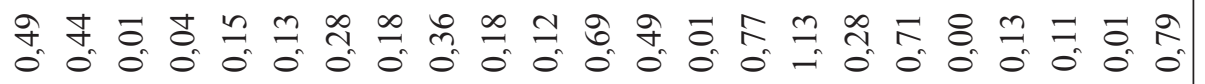

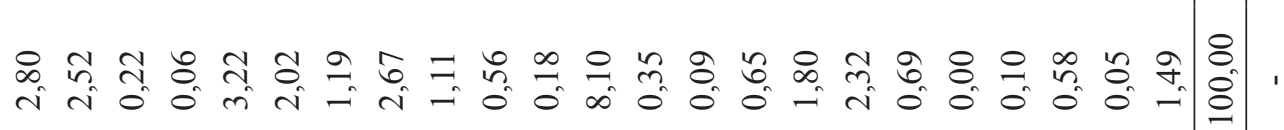

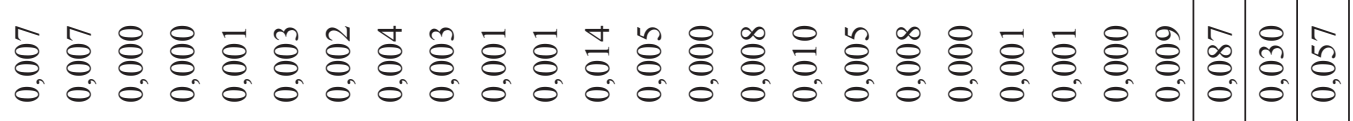

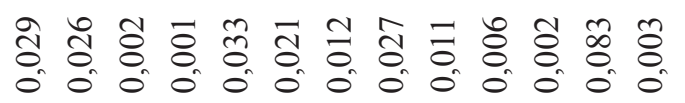

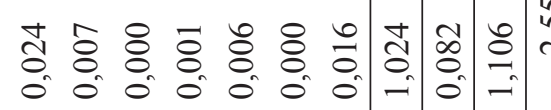

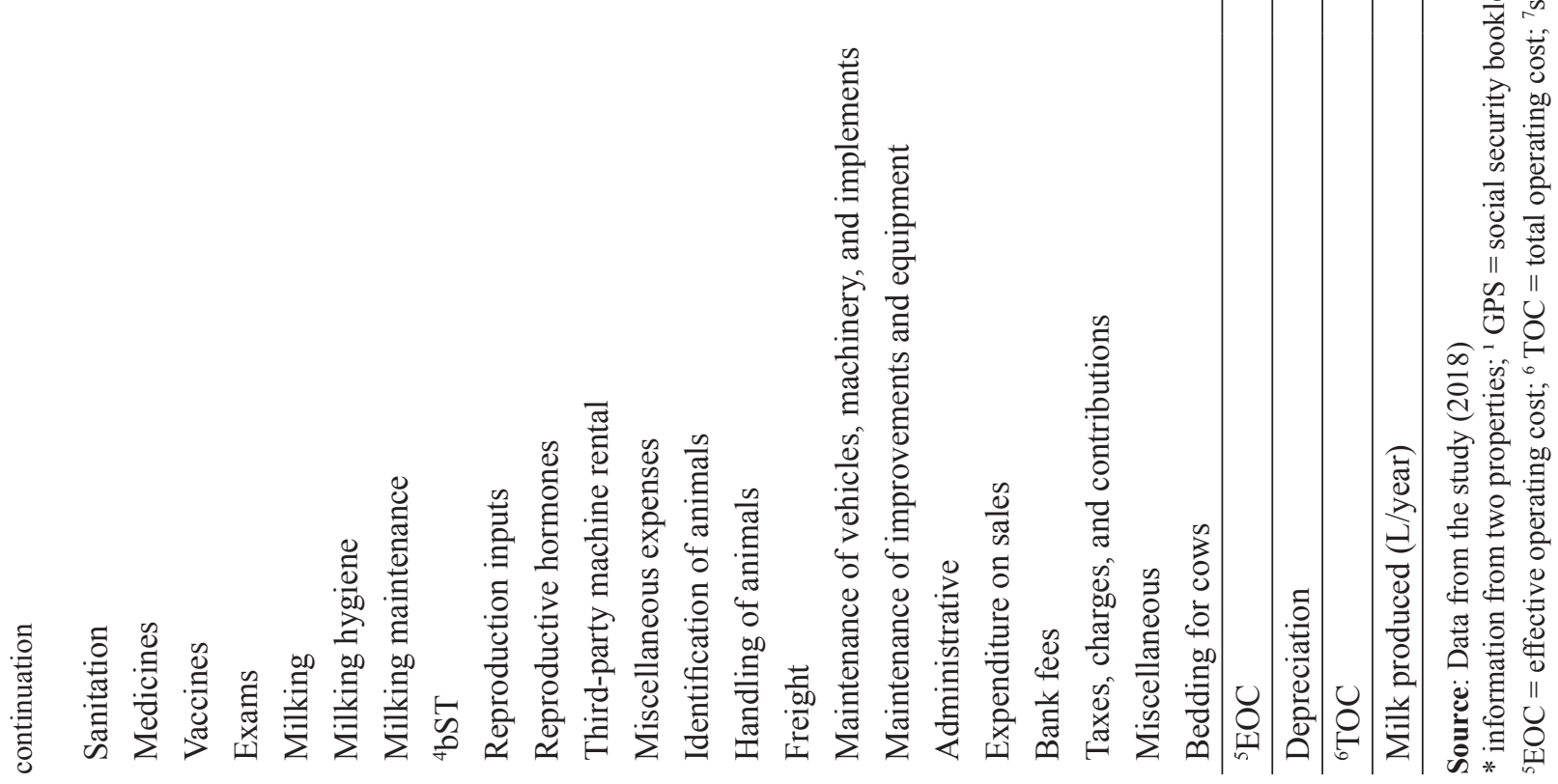


The values for technical assistance were similar in the two systems and not very representative (Table 2) in view of the great benefits that this can bring to rural properties; these benefits include, for example, improved milk quality, increased milk production, and higher profitability of the activity (GONÇALVES et al., 2014). Santos and Lopes (2012) reported that technical assistance represented a higher proportion $(5.8 \%)$ of the EOC in free stall properties, although there was a high standard deviation among the farms.

Electricity costs represented a lower percentage of the EOC in the free stall properties (Table 2), but the standard deviation was high $( \pm 2.86 \%)$. Farm 3 was responsible for this variation because it only had fans in the waiting room, whereas in the other three farms fans were also present in the sheds in which the cows were housed. Because fans are among the items that consume the most energy in dairy farms (due to the number required alongside the milking equipment and milk cooling tanks), in farm 3 the proportion was only $2.71 \%$ of the EOC. In farms 1 , 2 , and 4 , electricity represented $5.93 \%, 8.16 \%$, and $6.76 \%$, respectively, of the EOC. This indicates that the electricity cost proportion in the compost barn farms was close to that of the other free stall farm (farm 4). Therefore, the cost of electricity did not differ significantly between the two systems.

It was expected that there would be differences in the "electricity" item because in the compost barn system the fans are kept on throughout the day to dry the bedding and cool the animals, whereas in the free stall system the fans are only used to increase the thermal comfort of the cows. Nevertheless, since the free stall farms are located in regions in which the cows are under thermal stress for most of the year, it is necessary to leave them on for most of the day, which increases the electricity costs for these farms. Santos and Lopes (2012) reported a proportion of $3.18 \%$ of the EOC for this expenditure group.

Another item for which one might expect a difference in cost between the two types of facilities is the expenditure on fuels and lubricants, given that the management of the cow bedding is quite different in the compost barn and free stall systems. However, comparison of the production systems showed that the proportion was similar (Table 2). The compost barn farms had a higher standard deviation due to the high cost for farm $2(2.48 \%$ of EOC); the value for farm $1(1.24 \%)$ was close to the values for farms 3 and $4(1.71 \%$ and $1.64 \%$, respectively). Corroborating the values found in the present study, Santos and Lopes (2012) obtained an average of $1.54 \%$ of the EOC for fuels and lubricants.

Expenditures for medications comprised a lower percentage of the EOC in the compost barn properties (Table 2). This difference can be explained primarily by the lower expenditure on intramammary antibiotics for the treatment of mastitis; this is a significant expense in dairy farms and can represent an expenditure of between $\mathrm{R} \$ 0.0072$ and $\mathrm{R} \$ 0.1565$ per $\mathrm{kg}$ of milk produced when the prevalence of clinical mastitis varies from $1 \%$ to $15 \%$ (LOPES et al., 2012).

In farms 1 and 2, the cost of tubes for treating mastitis corresponded to $0.96 \%$ and $0.14 \%$ of the EOC, respectively, while in farms 3 and 4, the values were 2.30 and $3.07 \%$, respectively. The lower expenditure for this type of medication, which indicates a lower prevalence of clinical mastitis, and the lower somatic cell counts (SCC) (see Table 4) in the farms that adopted the compost barn system would seem to contradict the results obtained by Eckelkamp et al. (2016), Lobeck et al. (2011), and Petzen et al. (2009), who did not observe differences in the prevalence of mastitis or in SCC between compost barn and free stall farms. The differences found in the present study may have occurred due to management failures in the free stall properties and not because they are characteristic of this type of facility. According to Barberg et al. (2007) and Black et al. (2013), the SCC decreased after the animals were transferred to the compost barn. However, these cows had been 
maintained in different types of production systems (e.g., grazing and semi-confinement); thus, it cannot be concluded that improvement in this indicator would have occurred if the animals were placed in the free stall system.

Regarding milking hygiene, this component contributed a higher percentage of the EOC in the compost barn farms than in the free stall farms (Table 2). However, the standard deviation of the free stall farms was high; in farm 3, the value was $1.07 \%$, and in farm 4 it was $2.69 \%$, similar to the values for farms 1 and $2(2.12 \%$ and $1.93 \%$, respectively). This indicates that the difference between the two systems may not be due to the type of facility used by the property. Santos and Lopes (2012) reported that $1.1 \%$ of the EOC was spent on milking hygiene in free stall farms.

The proportion of the EOC represented by the cost of bovine somatotropin (bST) was similar in the two types of facilities (Table 2). This finding was also expected given that in all four farms a sound level of technology was used with regard to improvements in animal housing and equipment; according to Gillespie et al. (2010), improvements of this type are correlated with milk production and allow the animals to respond well to the application of bST, thus decreasing product costs. Furthermore, the mean cost of the bST dose was similar among the properties $(\mathrm{R} \$ 17.28, \mathrm{R} \$ 17.25, \mathrm{R} \$ 16.83$, and $\mathrm{R} \$ 16.95$ for farms $1,2,3$, and 4, respectively). However, Santos and Lopes (2012) found a proportion of $4.88 \%$ of the EOC for bST, despite the high standard deviation.

The average value spent on reproductive inputs was lower in the compost barn farms (Table 2); however, for the free stall farms, the standard deviation was high $( \pm 1.81 \%)$. This large variability was due to the high cost of reproductive inputs in farm 3, the only farm among the four to use embryo transfer technology, which made this cost more burdensome. Farm 4, in turn, had a proportion of $1.46 \%$, close to the average for the compost barn farms $(1.11 \%)$. Therefore, the costs for reproduction inputs do not appear to be affected by the type of facility used.

Expenditure for reproductive hormones (related to reproductive inputs) was also similar among the systems and not very representative in either type of facility (Table 2). This corroborates the results of Santos and Lopes (2012), who reported values of $0.86 \%$ for this component of the EOC. Barberg et al. (2007) and Black et al. (2013) reported that there were improvements in the reproductive rates after changing from other systems to the compost barn system.

Despite this, in many of the farms analysed by previous authors, the animals had been removed from the grazing system or from semi-confined systems, in which there may be high thermal stress and little comfort, and placed in a compost barn system; therefore, regardless of the system to which the cows were transferred (free stall or compost barn), a significant improvement in reproduction was expected. Thus, additional research comparing the reproductive rates of farms using the free stall and compost barn systems is needed so that the advantages of one system in relation to the other can be evaluated.

In the present study, the compost barn properties had a higher average service rate number of inseminated cows per number of cows apt to be inseminated) and a higher conception rate (number of pregnant cows per number of cows inseminated) (see Table 4).

The proportions of EOC related to the cow bedding were not very significant in either system. However, in the free stall properties, the proportion was lower than in the compost barn farms (Table 2). Farm 1 had the highest percentage of EOC (2.04\%), while farm 2 had $0.93 \%$, a proportion closer to that for the free stall farms $(0.10 \%$ and $0.75 \%)$. This result was expected given that the bedding area is smaller in the free stall system than in the compost barn and because in the free stall farms the sand was 
reutilized with the aid of a sand separator.

According to Kull et al. (2017), recycling of sand only once does not lead to the hygiene score of the cows rising above 1 , but it does increase the bacterial count in the udders of the cows, which may represent a risk of mastitis for the animals. However, studies are still needed to analyse the consequences of using sand that has been recycled several times and to determine the implications this practice may have for the development of mastitis. Thus, it would be possible to determine whether this practice causes an increase in SCC and in the incidence of mastitis; according to Smith et al. (1985), this would lead to greater spending on medications and a reduction in milk production, which could make the recycling of sand economically unviable.

The EOC per litre of milk was similar in the two types of facilities. Farms 1, 2, 3, and 4 had EOCs per litre of milk of $\mathrm{R} \$ 1.085, \mathrm{R} \$ 0.963, \mathrm{R} \$ 0.986$, and $\mathrm{R} \$ 1.035$, respectively (Table 2). Thus, a similarity can be seen in the costs of farms 1 and 4 and those of farms 2 and 3, which use different facilities. The data show that there are no significant differences in the EOC of the compost barn and free stall systems and that the differences observed in some groups of expenditure (medications and cow bedding) cancel each other out given that the farms in which the compost barn system was adopted expended a lower proportion of the EOC for medications, whereas the free stall farms expended a lower percentage of the EOC for cow bedding. For the EOC/TOC ratio, the compost barn farms had lower values due to their higher depreciation (Table 2). In confinement farms where the cows have access to pasture and in free stall properties, the EOC/TOC ratios were $92.77 \%( \pm 6.48)$ and $95.04 \%( \pm 1.84)$, respectively, according to Lopes et al. (2004b) and Santos and Lopes (2012).

Regarding the costs associated with treating hoof injuries and waste management, it is important to estimate the proportion of these items in isolation from the other components of the EOC; however, this was not possible because these expenses were not entered separately. Therefore, it is suggested that additional research be conducted with the aim of analysing these important components of the EOC.

The proportion of the TOC represented by depreciation was higher in the compost barn properties than in the free stall properties; however, the standard deviation was high (3.06\%). This variation occurred due to the high percentage found for farm $2(9.66 \%)$, which had improvements and idle equipment; for farm 1 , depreciation represented $5.33 \%$ of the TOC, a value close to that of farms $3(4.01 \%)$ and $4(5.86 \%)$. Thus, it can be seen that there was no significant difference in the production systems. This finding was expected because the patrimony values, which do not take into consideration the land values of the farms with compost barn and free stall facilities, were similar (Table 1), as was the TOC (Table 2).

According to Lopes et al. (2004b), depreciation represented $15.21 \%, 15.52 \%$, and $7.23 \%$ of the TOC in farms with production of $111.18( \pm 57.11)$, $268.85( \pm 85.02)$, and $1,421.65( \pm 992.23) \mathrm{kg}$ of milk per day, respectively. Santos and Lopes (2012) reported depreciation of $4.97 \%$ of the TOC in free stall properties with an average daily production of $6,227 \mathrm{~kg}$. Thus, the present study corroborates the data of these two studies, indicating that in farms with larger scales of production depreciation made up a smaller proportion of the TOC (Table 2) due to better use of the infrastructure.

In relation to improvements, depreciation was similar in the compost barn and free stall farms (Table 3), while in terms of equipment, the percentage was higher in the free stall farms due to the higher value of the milking equipment, given that these farms had more milking units. However, the standard deviation in the free stall farms was high (Table 3) due to the value for farm 3, which had higher depreciation due to its milk cooling tanks and irrigation system. 
Table 3. Proportions of depreciation represented by different groups of assets in four compost barn and free stall production systems located in the state of Minas Gerais for the period January to December 2016.

\begin{tabular}{ccccc}
\hline \multirow{2}{*}{ Specification } & \multicolumn{2}{c}{ Compost barn* $^{*}$ Free stall $^{*}$} \\
\cline { 2 - 5 } & $\%$ & $\mathbf{1} \mathbf{s d} \mathbf{~ ( \% )}$ & $\%$ & 1 sd (\%) \\
\hline Improvements & 36,66 & 1,20 & 37,79 & 2,96 \\
Equipment & 25,55 & 0,80 & 41,27 & 12,63 \\
Implements & 11,02 & 3,04 & 11,18 & 5,78 \\
Machinery & 18,74 & 4,68 & 7,57 & 0,79 \\
Vehicles & 8,03 & 5,72 & 2,19 & 3,09 \\
\hline Total & 100,00 & - & 100,00 & - \\
\hline
\end{tabular}

Source: Data from the study (2018)

* information from two properties; ${ }^{1} \mathrm{sd}=$ standard deviation; average exchange rate in 2016: US\$1 $=\mathrm{R} \$ 3.48$.

Regarding the value of implements, similarity was observed in the systems studied, despite a higher standard deviation in the free stall system (Table 3). The proportion of the value represented by the machines was quite divergent among the facilities; it was higher in the compost barn farms (Table 3) because these properties had more tractors. However, this significant difference should not be related to the type of facility because both systems require tractors to handle the bedding. In the compost barn system, tractors are used to turn the bedding over, while in the free stall system they are used to remove sand from the sand separator, turn the sand over to dry, and replace the bedding in the shed. Thus, the different percentages in the two types of systems may have occurred due to the idleness of the machines in the compost barn farms. Additionally, the standard deviation was high in the compost barn farms given that farm 2 had three more tractors than farm 1 .

The proportion of the TOC represented by vehicle depreciation was higher in the compost barn farms, but there was a high standard deviation in these properties (Table 3), which may have occurred due to the idleness of vehicles in farm 1. Furthermore, the low percentage in the free stall properties was because farm 3 did not have its own vehicles; it paid for the services provided and paid its employees for fuel plus a maintenance fee to use their own vehicles in some activities. Thus, the cost of third- party services for this property was greater than that for farm 4, which, in turn, had few vehicles, some of which were used in various sectors of the farms their depreciation was prorated between activities.

When analysing the depreciation of the compost barn and free stall sheds (where the cows are housed) with their respective fans and waste management structures, it could be seen that the proportion was $2.04 \%( \pm 0.92)$ in the compost barn system, $32.46 \%$ higher than in the free stall system, which had a proportion of $1.54 \%( \pm 0.62)$. However, the standard deviation in the compost barn system was high because farm 2 had higher depreciation $(2.69 \%)$ due to its possession of a biodigestor that was underutilized. Farm 3 had a low percentage $(1.11 \%)$ due to not having fans in the free stall area, while farms 1 and 4 had similar values of $1.39 \%$ and $1.98 \%$, respectively. Thus, no major differences between facility types were observed.

The TOC of the compost barn farms was higher than that of the free stall properties; however, both systems showed high standard deviation. Farms 1, 2,3 , and 4 had TOCs per litre of milk of $\mathrm{R} \$ 1.146$, $\mathrm{R} \$ 1.066, \mathrm{R} \$ 1.027$, and $\mathrm{R} \$ 1.099$, respectively. Thus, it can be seen that the TOC for properties 2, 3, and 4 was similar and that only farm 1 had a cost much different than that of the others; no significant differences in TOC were noted between the production systems. 
Despite this, it is important to highlight that the lower average productivity per cow of the free stall farms studied (Table 4) may have contributed to increasing the unit production cost of these properties. Moreover, it is important to note that these lower averages may have occurred due to failures in management or as a result of other issues not related to the type of facility given that according to Bewley et al. (2001) there are free stall farms that have higher production/cow/day averages. Therefore, if studies of free stall farms are conducted and they have averages similar to compost barn properties, it is possible that the TOC of the free stall farms would be even lower.

The production of milk per area differed among the studied farms, but no significant difference between the production systems was observed. Farm 1 (compost barn), for example, had production higher than that of farm 3 but slightly lower than that of farm 4, both of which are free stall properties (Table 4). Additionally, when the farms of the present study are compared with those described by Santos and Lopes (2012), a large difference in production per area can be seen. These researchers reported average milk production of $11,108 \mathrm{~kg} / \mathrm{ha}$ in free stall farms, a value far below that found in the systems analysed in this study. It is possible that this significant increase in production per hectare occurred due to the increased level of technology used in the properties, improvement in nutritionrelated aspects, and the genetic evolution of the herd.

As for the operational break-even point (LOPES et al., 2015), it can be seen that it was not affected by the type of facility, given that farms 1 and 2 had values higher than that of farm 3 but lower than that of farm 4 (Table 4). This finding was expected because the depreciation also varied widely among the properties. All of the farms not only attained the break-even point but exceeded it (by $85.19 \%$, $82.42 \%, 92.12 \%$, and $83.96 \%$ for properties 1 , 2,3 , and 4 , respectively), indicating that all were profitable. However, at no production level (low, medium, or high) were the farms studied by Lopes et al. (2016) able to attain the operational breakeven point.

As for the EOC/milk price (\%) and TOC/milk price $(\%)$ ratios, the values found in this study are lower (see Table 4) than those found by Santos and Lopes (2012), who reported averages of 96.99 and $102.12 \%$, respectively. This indicates that the systems analysed in the present study are more profitable. In terms of expenditure for concentrate/ milk price (Table 4), a more advantageous ratio was seen in the farms of the present study than in the farms studied by Santos and Lopes (2012); this may be due to lower price of the concentrate, higher milk prices, and better feed conversion by the animals (HILL; WALL, 2017).

As a percentage of the actual revenue, revenue from milk sales was higher in the free stall properties (93.3\%) than in the compost barn properties $(90.85 \%)$. This was due to the higher share of the sale of animals $(9.15 \%)$ in the composition of the revenues of the compost barn farms, although the standard deviation was very high (10.28\%). This variation can occur because the number of animals to be sold depends on the objectives of each farm (e.g., whether the herd is stabilized or in expansion), and it also depends on the wastage rate. In confinement systems with access to pasture, Lopes et al. (2004b) reported proportions of $90.31 \%( \pm 8.99)$ for the sale of milk and $9.70 \%( \pm 8.99)$ for the sale of animals. On the other hand, when studying free stall farms, Santos and Lopes (2012) estimated percentages of $97.81 \%( \pm 1.40)$ and $2.19 \%( \pm 1.40)$ for the sale of milk and animals, respectively.

For milk revenue expressed in reals per litre produced, a higher value was observed in compost barn farms $(\mathrm{R} \$ 1.507 \pm 0.032)$ than in free stall farms $(\mathrm{R} \$ 1.458 \pm 0.048)$. However, this parameter suffers interference from many other factors that are not determined by the type of facility, including the subsidies offered by dairy factories for milk quality (PAIXÃO et al., 2014, 2017; TEIXEIRA JÚNIOR et al., 2015), production scale (DEMEU et al., 2015, 
2016), and milk price in the region where the farm is located, which is defined by competition between dairy factories and the market in general. Because the revenue in reals per litre of milk is calculated based on the milk produced and not on the milk sold, the amount of milk discarded by the farm also affects the value because this milk is considered to have a value of zero.
Regarding the revenue from wastes, it is important to note that in the compost barn farms the bedding had not been changed prior to this study; therefore, it had not been sold or used in the milk production system itself. According to Lopes et al. (2004a), the latter could reduce the cost of forage production given that smaller amounts of chemical fertilizers would be required for production; however, it initially results in a reduction in revenue.

Table 4. Comparison of technical/managerial and economic indices for compost barn and free stall production systems located in the state of Minas Gerais for the period January to December 2016.

\begin{tabular}{lcccccc}
\hline \multirow{2}{*}{ Specification } & \multicolumn{3}{c}{ Compost barn* } & \multicolumn{3}{c}{ Free stall* } \\
\cline { 2 - 7 } & Farm 1 & Farm 2 & Average & Farm 3 & Farm 4 & Average \\
\hline${ }^{1}$ SCC (thousands of cells per mL) & 295 & 212 & 254 & 372 & 397 & 385 \\
${ }^{2}$ TBC (thousands of $\left.{ }^{3} \mathrm{CFU} / \mathrm{mL}\right)$ & 20 & 28 & 24 & 98 & 272 & 185 \\
Conception rate (\%) & 35 & 43 & 39 & 26 & 33 & 30 \\
Service rate (\%) & 72 & 63 & 68 & 59 & 70 & 65 \\
Productivity (kg/cow/day) & 27,3 & 33,1 & 30,2 & 21,1 & 23,1 & 22,1 \\
Milk production/area (kg/ha/year) & 29.487 & 23.245 & 26.366 & 27.288 & 33.087 & 30.187 \\
$\begin{array}{l}\text { Daily operational break-even } \\
\text { point (kg of milk) }\end{array}$ & 1.253 & 1.050 & 1.151 & 764 & 1.334 & 1.049 \\
$\begin{array}{l}\text { Annual operational break-even } \\
\text { point (kg of milk) }\end{array}$ & 458.493 & 384.219 & 421.356 & 279.618 & 488.143 & 383.880 \\
$\begin{array}{l}\text { Remuneration of capital without } \\
\text { animals and land (\% p.a.) }\end{array}$ & $155.235,00$ & $196.827,11$ & 176.031 & 96.035 & 172.005 & 134.020 \\
$\begin{array}{l}\text { Remuneration of capital with land } \\
\text { (\% p.a.) }\end{array}$ & $407.235,00$ & $535.227,11$ & 471.231 & 291.035 & 282.405 & 286.720 \\
${ }^{4}$ EOC/milk price (\%) & 73,07 & 62,93 & 68,00 & 66,05 & 72,66 & 69,35 \\
${ }^{5}$ TOC/milk price (\%) & 77,18 & 69,65 & 73,42 & 68,81 & 77,18 & 73,00 \\
$\begin{array}{l}\text { Expenditure on concentrate/milk } \\
\text { price (\%) }\end{array}$ & 26,53 & 30,80 & 28,67 & 32,97 & 27,62 & 30,30 \\
\hline
\end{tabular}

Source: Data from the study (2018)

* information from two properties; ${ }^{1} \mathrm{SCC}=$ somatic cell count; ${ }^{2} \mathrm{CBT}=$ total bacteria count; ${ }^{3} \mathrm{CFU}=$ colony-forming units; ${ }^{4} \mathrm{EOC}=$ effective operating cost; ${ }^{5} \mathrm{TOC}=$ total operating cost; average exchange rate in 2016: US\$1 $=\mathrm{R} \$ 3.48$.

In the free stall properties, the slurry produced cannot be commercialized because its transport is impractical due to the low amount of dry matter. Therefore, most of the time it can be used by the fodder production cost centre and is used on the farm itself. The manure produced in these properties had already been used as fertilizer for the maize crops to reduce the cost of bulk feed, which represented
$15.24 \%( \pm 2.83)$ and $14.10 \%( \pm 1.09)$ of the EOC in compost barn and free stall farms, respectively. Therefore, in the present work, expectations of revenue (if sold) from the compost barn bedding and from the free stall manure were presented separately. However, in the farms that adopted the free stall system, there were no estimated gross or net margins (Table 5) because the slurry could not 
be sold, and the manure was already being used for forage production.

When the expected revenue from wastes was included, it was found that this item represented $1.23 \%( \pm 0.13)$ and $1.29 \%( \pm 0.01)$ of the revenues in the compost barn and free stall properties, respectively. Thus, a fairly similar proportion of total revenue is obtained from wastes in both types of facility, and the proportion of total revenue obtained from wastes per litre of milk was also similar (see Table 6). However, Lopes et al. (2005) reported $0.8 \%( \pm 1.6)$ and $0.7 \%( \pm 1.2)$ as the shares of wastes in the revenue of farms with low and medium technological levels, respectively. Lopes et al. (2006), in turn, reported percentages of $0.63 \%$ and $0.74 \%$ of this item for small and medium producers, respectively. According to Lopes et al. (2007a), the percentage of revenue from the sale of wastes was $0.65 \% \%, 1.96 \%$, and $3.64 \%$ for grazing, semi- confinement, and confinement breeding systems, respectively. All of these researchers reported having observed wastage of this by-product due to inadequate storage conditions.

When only the actual revenue was considered, the gross margin was higher in the free stall farms; however, the standard deviation was very high for both types of facility (Table 5). This was expected given that the gross margin depends on various factors such as the quality of the milk produced, the price of milk in the region, and the quantity and quality of the animals sold. However, it cannot be concluded that the compost barn properties have a lower gross margin given that farm 1 , for example, had a gross margin higher than farm 4 and very similar to that of farm 3 . Farm 2 , in turn, had the lowest gross margin among the four due to its smaller production scale and fewer sales of animals.

Table 5. Summary of the profitability analysis (in R\$) of the milk production cost centre in compost barn and free stall production systems located in the state of Minas Gerais for the period January to December 2016.

\begin{tabular}{lcccc}
\hline \multirow{2}{*}{ Specification } & \multicolumn{2}{c}{ Compost barn* } & \multicolumn{2}{c}{ Free stall } \\
\cline { 2 - 5 } & Average $(\mathrm{R} \$)$ & ${ }^{8}$ sd $(\mathrm{R} \$)$ & Average $(\mathrm{R} \$)$ & ${ }^{8}$ sd $(\mathrm{R} \$)$ \\
\hline${ }^{1}$ Revenue & $4.292 .657,21$ & $1.424 .612,77$ & $5.007 .803,69$ & $802.098,05$ \\
Milk & $3.847 .082,21$ & $859.740,52$ & $4.665 .006,15$ & $657.089,48$ \\
Animals & $445.575,00$ & $564.872,25$ & $342.797,55$ & $145.008,57$ \\
${ }^{2} \mathrm{TOC}$ & $2.847 .338,96$ & $835.981,80$ & $3.385 .865,78$ & $203.508,24$ \\
${ }^{3}$ EOC & $2.646 .699,20$ & $860.385,75$ & $3.219 .997,00$ & $237.737,79$ \\
Depreciation & $200.639,76$ & $24.403,95$ & $165.868,78$ & $34.229,55$ \\
${ }^{4}$ Gross margin & $1.645 .958,01$ & $564.227,02$ & $1.787 .806,69$ & $564.360,26$ \\
Gross margin/ha & $16.370,67$ & $4.390,89$ & $15.958,56$ & $1.221,20$ \\
${ }^{5}$ Net margin & $1.445 .318,26$ & $588.630,97$ & $1.621 .937,91$ & $598.589,81$ \\
Net margin/ha & $14.338,39$ & $4.795,02$ & $14.380,69$ & $1.911,53$ \\
Expected revenue from manure & $51.744,02$ & $12.075,87$ & $64.326,42$ & $9.908,87$ \\
${ }^{6}$ Estimated gross margin ** & $1.697 .702,04$ & $576.302,89$ & - & - \\
${ }^{7}$ Estimated net margin ** & $1.497 .062,28$ & $600.706,85$ & - & - \\
\hline
\end{tabular}

Source: Data from the study (2018)

* information from two properties; ** No gross or net margins were estimated in the free stall system because the manure had already been used in fertilizing the maize crops in these properties, thus reducing the cost of bulk feed; therefore, it could not be computed again. ${ }^{1}$ Revenue $=$ revenue actually received by the producer, coming only from the sale of milk and animals; ${ }^{2} \mathrm{TOC}$ $=$ total operating cost; ${ }^{3} \mathrm{EOC}=$ effective operating cost; ${ }^{4} \mathrm{Gross}$ margin $=$ considering only the actual revenue; ${ }^{5} \mathrm{Net}$ margin $=$ considering only the actual revenue; ${ }^{6}$ Estimated gross margin = considering actual revenue and expectation of revenue from wastes; ${ }^{7}$ Estimated net margin $=$ considering actual revenue and expectation of revenue from wastes; ${ }^{8} \mathrm{sd}=$ standard deviation; average exchange rate in 2016: US\$1 $=\mathrm{R} \$ 3.48$. 
Table 6. Revenue (in $\mathrm{R} \$$ and $\mathrm{R} \$ \mathrm{~L}$ ) from compost barn bedding and free stall manure in production systems located in the state of Minas Gerais for the period January to December 2016.

\begin{tabular}{ccccccccc}
\hline & \multicolumn{4}{c}{ Compost barn* } & \multicolumn{3}{c}{ Farm 2 } & \multicolumn{3}{c}{ Farm 3 } & \multicolumn{2}{c}{ Farm 4 } \\
\cline { 2 - 9 } Nutrients & $\mathrm{kg}$ & $\mathrm{R} \$$ & $\mathrm{~kg}$ & $\mathrm{R} \$$ & $\mathrm{~kg}$ & $\mathrm{R} \$$ & $\mathrm{~kg}$ & $\mathrm{R} \$$ \\
\cline { 2 - 9 } Nitrogen & 6.542 & $22.302,67$ & 3.702 & $12.619,21$ & 6.574 & $22.412,93$ & 5.283 & $18.009,95$ \\
Phosphorus & 4.371 & $17.590,16$ & 2.448 & $9.852,40$ & 4.781 & $19.242,32$ & 3.842 & $15.462,20$ \\
Potassium & 7.391 & $20.390,12$ & 7.516 & $20.733,48$ & 10.758 & $29.677,80$ & 8.645 & $23.847,65$ \\
\hline Total $(\mathrm{R} \$)$ & - & $60.282,95$ & - & $43.205,09$ & - & $71.333,05$ & - & $57.319,79$ \\
R $\$ / \mathrm{L}$ & - & 0,020 & - & 0,020 & - & 0,021 & - & 0,019 \\
\hline
\end{tabular}

Source: Data from the study (2018)

* information from two properties; Average exchange rate in 2016: US\$1 $=\mathrm{R} \$ 3.48$.

Additionally, both the compost barn farms and the free stall farms had positive gross margins; this indicates that they are able to produce in the short term, given that they are capable of covering the NOC and still have surpluses (LOPES et al., 2004a). For the gross margin/hectare, similar averages were observed in the different types of facility despite the high standard deviation for the compost barn farms (TABLE 5).

Considering only the actual revenue, the net margin, similar to the gross margin, was higher in the free stall farms; the standard deviation was very high for both types of facility (TABLE 5). This variation was due to the same reasons mentioned in relation to the gross margin and also to the high standard deviation of the depreciation in the farms studied and to the differences in production scale, given that a reduction in the product's unit cost can occur when the milk production of a farm is increased (BRESSAN et al., 2010) due to optimization of the physical structure of the property (LOPES et al., 2006) and keeping costs fixed (BANNOCK et al., 2003). Additionally, it was verified that farm 1 had a net margin close to that of farm 3 but greater than that of farm 4. Therefore, in the present work, the type of facility had no observable influence on the net margin of the properties.

It is also important to highlight that the net margin was positive in both the compost barn and free stall properties. These results show that the farms are able to produce in the medium term, given that the revenues are sufficient to cover the EOC and to replace the assets after they become worthless through depreciation (LOPES et al., 2004a). In relation to the net margin/hectare, similar averages were also seen in the compost barn and free stall properties, with a high standard deviation in the first (TABLE 5).

\section{Conclusions}

The gross and net margins were positive in all of the production systems studied, indicating that they are able to produce in the short and medium term.

By comparing the components of the TOC of the compost barn and free stall farms, it was concluded that there were differences only in the "medications" item, which constituted a lower proportion of the NOC of the compost barn properties due to the lower percentage expended for intramammary antibiotics for mastitis, and in the "bedding for cows" item, which represented the lowest proportion in the free stall system. In the costs of reproduction inputs and reproductive hormones, there were no significant differences between the farms adopting the different types of facility, although the compost barn farms had better reproductive rates. Additionally, with regard to depreciation, there was no significant difference in the production systems. 
Regarding the composition of the revenue, a higher percentage came from the sale of milk in the free stall properties because the compost barn properties sold more animals. In relation to the wastes, the revenue expectations were similar in the two systems.

These results show that the revenues, EOC, depreciation, and the cost of implementing the systemsmaynotbethemajordeterminantsindeciding which type of facility to build on a property. Thus, ease of management, productivity, reproductive performance, animal health (hoof injuries and mastitis), water availability, environmental issues, and availability of bedding material (sand, sawdust, coffee husks) should motivate the choice of one installation over the other.

\section{References}

ALBRIGHT, J. L. Dairy cattle housing with emphasis on economics, sanitation, health, and production. Journal of Dairy Science, Champaign, v. 47, n. 11, p. 1273-1281, 1964. DOI: $10.3168 /$ jds.S0022-0302(64)88898-6

AMERICAN SOCIETY OF AGRICULTURAL ENGINEERS - ASAE. Manure production and characteristics. Michigan: American National Standards, 2005. Available at: <http://www.agronext.iastate. edu/ immag/pubs/manure-prod-char-d384-2.pdf $>$. Accessed at: 6 abr. 2018.

BANNOCK, G. R. E.; BAXTER, R. E.; DAVIS, E. The penguin dictionary of economics. London: Penguin Books, 2003. $416 \mathrm{p}$.

BARBERG, A. E.; ENDRES, M. I.; SALFER, J. A.; RENEAU, J. K. Performance and welfare of dairy cows in an alternative housing system in Minnesota. Journal of Dairy Science, Champaign, v. 90, n. 9, p. 1575-1583, 2007. DOI: $10.3168 /$ jds.S0022-0302(07)71643-0

BEWLEY, J.; PALMER, R. W.; JACKSON-SMITH, D. B. A comparison of free-stall barns used by modernized Wisconsin dairies. Journal of Dairy Science, Champaign, v. 84 , n. 2 , p. $528-541,2001$. DOI: $10.3168 /$ jds.S00220302(01)74504-3

BLACK, R. A.; TARABA, J. L.; DAY, G. B.; DAMASCENO, F. A.; BEWLEY, J.M. Compost bedded pack dairy barn management, performance, and producer satisfaction. Journal of Dairy Science, Champaign, v. 96, n. 12 , p. $8060-8074,2013$. DOI: $10.3168 /$ jds.2013-6778
BRESSAN, V. G. F.; BRAGA, M. J.; BRESSAN, A. A. Eficiência e economia de escala em cooperativas de crédito: uma abordagem de fronteira estocástica de custo com dados em painel. Advances in Scientific and Applied Accounting, São Paulo, v. 3, n. 3, p. 335-352, 2010. DOI: 10.14392/ASAA.2010030304

BRITO, E. C. Produção intensiva de leite em compost barn: uma avaliação técnica e econômica sobre a sua viabilidade. 2016. Dissertação (Mestrado em Mestrado Profissional em Ciência e Tecnologia do Leite e Derivados) - Universidade Federal de Juiz de Fora, Juiz de Fora.

CORRÊA, U.; LOPES, M. A.; RIBEIRO, B. P. V. B.; BENEDICTO, G. C.; SILVA, I. M.; CÔRREA, B. W. A. Análise operacional da atividade leiteira do Instituto Federal de Ciência e Tecnologia de Minas Gerais Campus Bambuí.Custos e @gronegócio on line, Recife, v.13, p. 262-283. 2017. Edição Especial.

DEMEU, F. A.; LOPES, M. A.; COSTA, G. M.; ROCHA, C. M. B. M.; SANTOS, G. Efeito da produtividade diária de leite no impacto econômico da mastite em rebanhos bovinos. Boletim de Indústria Animal, Nova Odessa, v. 73, n. 1, p. 53-61, 2016.

DEMEU, F. A.; LOPES, M. A.; ROCHA, C. M. B. M.; COSTA, G. M.; SANTOS, G.; FRANCO NETO, A. Influência da escala de produção no impacto econômico da mastite em rebanhos bovinos leiteiros. Revista Ceres, Viçosa, MG, v. 62, n. 2, p. 167-174, 2015. DOI:

ECKELKAMP, E. A.; TARABA, J. L.; AKERS, K. A.; HARMON, R. J.; BEWLEY, J. M. Understanding compost bedded pack barns: Interactions among environmental factors, bedding characteristics, and udder health. Livestock Science, Amsterdam, v. 190, p. 35-42, 2016. DOI: 10.1016/j.livsci.2016.05.017

FERRAZZA, R. A.; LOPES, M. A.; BRUHN, F. R. P.; MORAES, F.; CARVALHO, F. M. Effect of husbandry system on the technical and economic performance of dairy cattle. Semina: Ciências Agrárias, Londrina, v. 38, n. 3, p. 1561-1574, 2017. DOI: $10.5433 / 1679-0359.2017 \mathrm{v} 3$ $8 \mathrm{n} 3 \mathrm{p} 1551$

GILLESPIE, J.; NEHRING, R.; HALLAHAN, C.; SANDRETTO, C.; TAUER, L. Adoption of recombinant bovine somatotropin and farm profitability: does farm size matter? AgBioForum, Columbia, v. 13, n. 3, p. 251262, 2010.

GONÇALVES, A. C. S.; ROMA JÚNIOR, L. C.; FONSECA, M. I.; NADRUZ, B. V.; BÜRGER, K. P.; ROSSI, G. A. M. Assistência técnica e extensão rural: sua importância para a melhoria da produção leiteira. Relato de caso. Revista Brasileira de Higiene e Sanidade 
Animal, Fortaleza, v. 8, n. 3, p. 47-61, 2014. DOI: 10.5935/1981-2965.20140116

HILL, D. L.; WALL, E. Weather influences feed intake and feed efficiency in a temperate climate. Journal of Dairy Science, Champaign, v. 100, n. 3, p. 1-18, 2017. DOI: $10.3168 /$ jds.2016-11047

HOOVEN, N. W.; MILLER, R. H.; PLOWMAN, R. D. Genetic and environmental relationships among efficiency, yield, consumption and weight of holstein cows. Journal of Dairy Science, Champaign, v. 51, n. 9, p. $1409-1419,1968$. DOI: 10.3168/jds.S00220302(68)87204-2

JANNI, K. A.; ENDRES, M. I.; RENEAU, J. K.; SCHOPER, W. W. Compost dairy barn layout and management recommendations. Applied Engineering in Agriculture, Saint Joseph, v. 23, n. 1, p. 97-102, 2007.

KIEHL, E. J. Fertilizantes orgânicos. Piracicaba: Editora Agronômica Ceres Ltda, 1985. 492 p.

KULL, J.A.; INGLE, H. D.; BLACK, R. A.; EBERHART, N. L.; KRAWCZEL, P. D. Effects of bedding with recycled sand on lying behaviors, udder hygiene, and preference of lactating Holstein dairy cows. Journal of Dairy Science, Champaign, v. 100, n. 9, p. 7379-7389, 2017. DOI: $10.3168 /$ jds.2016-12307

LESO, L.; UBERTI, M.; MORSHED, W.; BARBARI , M. A survey of Italian compost dairy barns. Journal of Agricultural Engineering, Pavia, v. 44, n. 3, p. 4-8, 2013. DOI: $10.4081 /$ jae.2013.e17

LOBECK, K. M.; ENDRES, M. I.; SHANE, E. M.; GODDEN, S. M.; FETROW, J. Animal welfare in cross-ventilated, compost-bedded pack, and naturally ventilated dairy barns in the upper Midwest. Journal of Dairy Science, Champaign, v. 94, n. 11, p. 5469-5479, 2011. DOI: $10.3168 /$ jds.2011-4363

LOPES, M. A.; CARDOSO, M. G.; CARVALHO, F. M.; LIMA, A. L. R.; DIAS, A. S.; CARMO, E. A.; Efeito do tipo de sistema de criação nos resultados econômicos de sistemas de produção de leite na região de Lavras (MG) nos anos 2004 e 2005. Ciência Animal Brasileira, Goiânia, v. 8, n. 3, p. 359-371, 2007a.

LOPES, M. A.; DIAS, A. S.; CARVALHO, F. M.; LIMA, A. L. R.; CARDOSO, M. G.; CARMO, E. A. Efeito da escala de produção nos resultados econômicos de sistemas de produção de leite na região de Lavras (MG): um estudo multicasos. Boletim de Indústria Animal, Nova Odessa, v. 63, n. 3, p. 177-188, 2006.

LOPES, M. A.; LIMA, A. L. R.; CARVALHO, F. M.; REIS, R. P.; SANTOS, I. C.; SARAIVA, F. H. Controle gerencial e estudo da rentabilidade de sistemas de produção de leite na região de Lavras (MG). Ciência e Agrotecnologia, Lavras, v. 28, n. 4, p. 883-892, 2004a.

LOPES, M. A.; LIMA, A. L. R.; CARVALHO, F. M.; REIS, R. P.; SANTOS, I. C.; SARAIVA, F. H. Efeito do tipo de sistema de criação nos resultados econômicos de sistemas de produção de leite na região de Lavras (MG). Ciência e Agrotecnologia, Lavras, v. 28, n. 5, p. 11771189, 2004b. DOI: 10.1590/S1413-70542004000500028

LOPES, M. A.; LIMA, A. L. R.; CARVALHO, F. M.; REIS, R. P.; SANTOS, I. C.; SARAIVA, F. H. Resultados econômicos de sistemas de produção de leite com diferentes níveis tecnológicos na região de Lavras, MG. Arquivo Brasileiro de Medicina Veterinária e Zootecnia, Belo Horizonte, v. 57, n. 4, p. 485-493, 2005.

LOPES, M. A.; MORAES, F.; CARVALHO, F. M.; PERES, A. A. C.; BRUHN, F. R. P.; REIS, E. M. B. Effect of technical indexes on cost-effectiveness in dairy farms participating in the Balde Cheio program at different stages of production. Semina: Ciencias Agrarias, Londrina, v. 37, n. 6, p. 4235-4242, 2016. DOI: 10.5433/1679-0359.2016v37n6p4235

LOPES, M. A.; MORAES, F.; CARVALHO, F. M.; PERES, A. A. C.; BRUHN, F. R. P.; REIS, E. M. B. The effect of technological levels on profits of milk production systems participating in the full bucket program: a multicase study. Semina: Ciências Agrárias, Londrina, v. 36, n. 4, p. 2909-2922, 2015. DOI: 10.5433/1679-0359.2015v36n4p2909

LOPES, P. F.; REIS, R. P.; YAMAGUCHI, L. C. T. Custos e escala de produção na pecuária leiteira: estudo nos principais estados produtores do Brasil. Revista de Economia e Sociologia Rural, Brasília, v. 45, n. 3, p. 567590, 2007b. DOI: 10.1590/S0103-20032007000300002

LOPES, M. A.; DEMEU, F. A.; ROCHA, C. M. B. M. da; COSTA G. M. da; FRANCO NETO, A.; SANTOS, G. dos. Avaliação do impacto econômico da mastite em rebanhos bovinos leiteiros. Arquivos do Instituto Biológico, São Paulo, v.79, n.4, p.477-483. 2012.

MATSUNAGA, M.; BEMELMANS, P. F.; TOLEDO, P. E. N.; DULlEY, R. D.; OKAWA, H.; PEDROSO, I. A. Metodologia do custo de produção utilizada pelo IEA. Instituto de Economia Agrícola, São Paulo, v. 23, n. 1, p. 123-139, 1976.

PAIXÃO, M. G.; LOPES, M. A.; COSTA, G. M.; SOUZA, G. N.; ABREU, L. R.; PINTO, S. M. Milk quality and financial management at different scales of production on dairy farms located in the south of Minas Gerais state. Revista Ceres, Viçosa, MG, v. 64, n. 3, p. 213-221, 2017. DOI: 10.1590/0034-737x201764030001 
PAIXÃO, M. G.; LOPES, M. A.; PINTO, S. M.; ABREU, L. R. Impacto econômico da implantação das boas práticas agropecuárias relacionadas à qualidade do leite. Revista Ceres, Viçosa, MG, v. 61, n. 5, p. 612-621, 2014. DOI: 10.1590/0034-737X201461050003

PETZEN, J.; WOLFANGER, C.; BONHOTAL, J.; SCHWARS, M.; TERRY, T.; YOUNGERS, N. Case study: eagleview compost dairy barn. New York: Cornell University, 2009. $11 \mathrm{p}$.

SANTOS, G.; LOPES, M. A. Indicadores de rentabilidade do centro de custo produção de leite em sistemas intensivos de produção. Boletim de Indústria Animal, Nova Odessa, v. 69, n. 1, p. 1-11, 2012.

SMITH,L.K.; TODHUNTER,D.A.;SCHOENBERGER, P. S. Environmental mastitis: cause, prevalence, prevention. Journal of Dairy Science, Champaign, v. 68 , n. 6 , p. 1531-1553, 1985. DOI: 10.3168/jds.S00220302(85)80993-0
TEIXEIRA JÚNIOR, F. E. P.; LOPES, M. A.; RUAS, J. R. M. Efeito do pagamento por qualidade do leite na rentabilidade da atividade leiteira. Revista do Instituto de Laticinios Cândido Tostes, Juiz de Fora, v. 70, n. 1, p. $24-$ 34, 2015. DOI: 10.14295/2238-6416.v70i1.375

TEIXEIRA JÚNIOR, F. E. P.; RUAS, J. R. M.; LOPES, M. A.; COSTA, M. D.; PIRES, D. A. A.; ROCHA JÚNIOR, V. R. Effect of different alternative roughages on the profitability of milk production systems with F1 Holstein x Zebu cows. Revista Ceres, Viçosa, MG, v. 63, n. 6, p. 807-815, 2016. DOI: 10.1590/0034-737X201663060009

VILLELA, S. D. J.; ASSIS, L. P.; LOPES, M. A.; SILVESTRE, L. H. A.; SANTOS, R. A.; RESENDE, E. S.; MARTINS, P. G. M. A. Economic and productive assessment of an ordinary small-sized dairy enterprise in southeast Brazil: A multi-year study. Journal of Agricultural Science, Richmond Hill, v. 9, n. 8, p. 143154, 2017. DOI: $10.5539 /$ jas.v9n8p143

YAMAGUCHI, L. C. T. Custo de produção do leite: um novo enfoque. Boletim do Leite, Piracicaba, v. 7, n. 76, p. 1-2, 2000. 
